Research papers

\title{
Multilevel and structural equation modeling approach to identify spatiotemporal patterns and source characterization of metals and metalloids in surface water and sediment of the Ctalamochita River in Pampa region, Argentina
}

\author{
Leonardo Lupi ${ }^{\mathrm{a}}$, Lidwina Bertrand ${ }^{\mathrm{b}}$, Magdalena Victoria Monferrán ${ }^{\mathrm{b}}$, María Valeria Amé ${ }^{\mathrm{b}}$, \\ Maria del Pilar Diaz ${ }^{\mathrm{a}, \mathrm{c}, *}$ \\ ${ }^{a}$ Instituto de Investigaciones en Ciencias de las Salud-INICSA-CONICET, Facultad de Ciencias Médicas, Universidad Nacional de Córdoba (5000), Argentina \\ ${ }^{\mathrm{b}}$ Centro de Investigaciones en Bioquímica Clínica e Inmunología - CIBICI, Facultad de Ciencias Químicas, CONICET, Universidad Nacional de Córdoba (5000), Argentina \\ ${ }^{\mathrm{c}}$ Escuela de Nutrición, Facultad de Ciencias Médicas, Universidad Nacional de Córdoba (5000), Argentina
}

\section{A R T I C L E I N F O}

This manuscript was handled by Huaming Guo, Editor-in-Chief, with the assistance of Pedro J.J. Depetris, Associate Editor

Keywords:

Natural and anthropogenic sources

Pollution hotspots

River water quality

Factor analysis

Multilevel and structural equation model

\begin{abstract}
A B S T R A C T
Simple models capable of describing spatial and temporal patterns of pollutants are needed to understand surface water quality and to identify the main processes that influence the fate and transport of pollutants. This study combines exploratory factor analysis with multilevel and structural equation modeling to: find spatial and temporal patterns of metal and metalloids in the Ctalamochita River Basin (Argentina); identify the processes responsible for the occurrence of these elements; and, establish relationships between latent variables of different aquatic compartments. For this purpose, the metal and metalloid concentration in different matrices was analyzed at sampling sites along $330 \mathrm{~km}$ of the river course, including seasonal variations. Our results indicate that the concentration of natural occurring elements in surface water increased downstream the catchment and during the warm-rainy season, as a consequence of surface runoff and groundwater discharge. In contrast, the spatial and seasonal variation in sediment showed an inverse pattern (negative correlation) compared to surface water. On the other hand, copper, zinc and lead were derived from anthropogenic sources, such as old mining areas and metal industries. Moreover, the input of these metals into the river evidenced a direct effect of surface water on sediment. Overall, the combined use of multilevel model and SEM allowed for a proper description of spatial and temporal patterns of metals and metalloids in the catchment, and successfully highlighted sources and processes influencing metal transport. The proposed methodological framework could be extended to wider spatial scales including nested regions, and could be applied to environmental studies dealing with repeated observations and multiple matrices.
\end{abstract}

\section{Introduction}

The metals and metalloids are released into the environment through natural processes and by human activity. The weathering of parent rocks and soil particles constitute a natural source of metals, while urban runoff, municipal sewage discharges, agricultural and industrial activity represent anthropogenic sources (van der Perk, 2014). It is worth mentioning that human activities are likely to be the main source of metals in drinking water, when surface water is used as water resource (Chowdhury et al., 2016). Metal polluted environments may affect food quality, increasing the exposure, uptake and magnification of metals through the food chain, which constitute a risk to human health (Bortey-Sam et al., 2018; Lu et al., 2015). The assessment of metal pollution and other contaminants in pristine and impacted aquatic environments is important to reduce the consequences of human activities and to enable water use and reuse (Sabater et al., 2012).

Sustainability of surface water and groundwater resources is being increasingly threatened by pesticides, deforestation, agricultural practices and land-use changes in Argentina (FAO, 2016). Many studies have evaluated the uptake of metals by aquatic organisms and the grade of pollution in different environments, including marine and freshwater habitats (Amin et al., 1996; Arribére et al., 2003; Avigliano et al., 2015; Beltrame et al., 2009; Gagneten et al., 2007; Marcovecchio et al., 2010;

\footnotetext{
* Corresponding author at: Av. de la Reforma (Ex E. Barros) y Enf. Gordillo S/N, Córdoba (5016), Córdoba, Argentina.

E-mail address: pdiaz@fcm.unc.edu.ar (M.d.P. Diaz).
} 


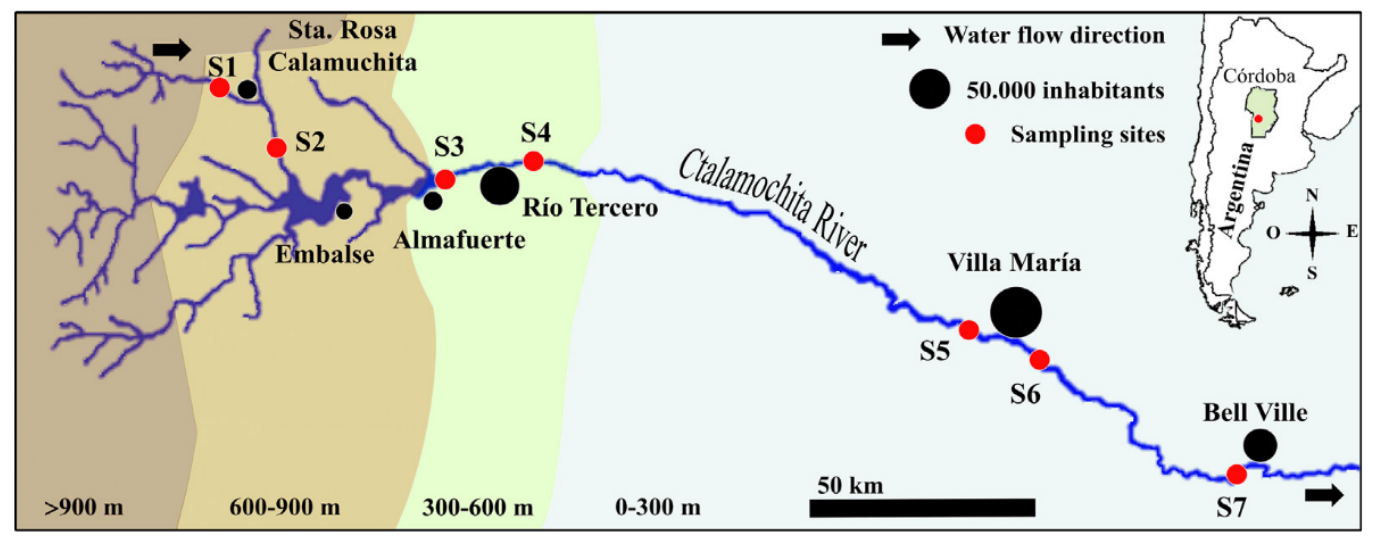

Fig. 1. Study area and sampling sites in the Ctalamochita River catchment.

Muse et al., 1999; Rigacci et al., 2013; Schenone et al., 2014, 2007). Some were carried out in Córdoba Province, Argentina, mainly in the Suquía River and Xanaes River Catchments (Gaiero et al., 1997; Griboff et al., 2018; Harguinteguy et al., 2016, 2014, 2013; Merlo et al., 2011; Monferrán, 2015; Monferrán et al., 2016, 2011). Research efforts have been directed to establishing background levels, identify hot-spot of metal pollution and assign potential sources. Usually, the available studies analyze the information by comparing the concentration of individual elements between sampling stations, rather than to conclude from the underlying factors responsible for such pollution. Sometimes multivariate statistics are also included. For example, principal component analysis is widely applied in environmental science and spatial data (Demšar et al., 2013) and it is frequently employed to reduce dimensionality and to group samples of similar chemical composition (Baroni and Wunderlin, 2017). However, studies on statistical methods that tended to identify the underlying processes involved in the spread of pollution have received little attention in this research area. Such research works would be useful to better understand the transport of contaminants and temporal variations, in addition to the establishment of relationships between environmental compartments.

Simple and reliable models capable of describing spatial and temporal trends are useful to understand surface water pollution. Multilevel models have been used with this purpose for assessing surface water and groundwater quality (Benson et al., 2007; Hwang et al., 2016; Ryan et al., 2000). While multilevel models enable a proper description of dataset with 'natural' hierarchical levels of structure (Rabe-Hesketh and Skrondal, 2012), structural equation models (SEM) allow for exploration of theoretical and empirical relationships of variables in a network form (Skrondal and Rabe-Hesketh, 2004). SEM analysis has been widely used in social science, and its application in environmental science has gained relevance over the last few years (Angelini et al., 2016; Li et al., 2018; Reckhow et al., 2005; Villeneuve et al., 2018; Zou and Yu, 1993). However, SEM application in aquatic environments and pollution research is still uncommon. SEM include confirmatory factor analysis, which can be used to identify underlying processes or unmeasured 'latent' variables.

Environmental driving forces condition pollutant concentration in the aquatic environment. Hence, the underlying processes should simultaneously operate in different matrices. It is hypothesized that concentrations of metals and metalloids in different matrices are linked by the same processes and sources, showing some degree of correspondence and effect between them. With this in mind, the main objectives of this study were to identify the latent variables responsible for the fate and transport of metals and metalloids in the Ctalamochita River Catchment in the province of Córdoba and to establish relationships between constructs for different aquatic compartments (surface water and sediments). The topographic features vary from mountains to plains along the entire catchment. Some of the human activities that take place in the Ctalamochita River are: hiking and trekking tourism, metal and petrochemical industries, agriculture, trade and services. To accomplish these aims, an exploratory principal component factor analysis (PC-FA) was initially used to identify sources and trends of pollution by metals, metalloids and other inorganic constituents in surface water and the surrounding aquatic environment (sediment and macrophyte). After a confirmatory analysis, the latent variables were modeled to assess the spatial and temporal patterns in a multilevel approach. Finally, to investigate the validity of the underlying driving forces that influence the centration of metals and metalloids in the watershed, the hypothetical latent variables and their relation between matrices were assessed by using SEM.

\section{Material and methods}

\subsection{Study area and sampling sites}

The Ctalamochita River watershed $\left(3287 \mathrm{~km}^{2}\right)$ is located in the south-west of Córdoba province, Argentina. It drains west-east from the Calamuchita to the Union department. Seven sampling sites (S1-S7) were settled upstream and downstream of the selected towns, spanning $330 \mathrm{~km}$ along the river course (Fig. 1). The main recharge area is located in the upland region, which is characterized by a hilly landscape and streams with a step-pool morphology (in the vicinity of S1 and S2), while in the middle (S3 and S4) and lowland regions (S5, S6 and S7) meandering channels predominate. The climate is temperate [17-31 $\left.{ }^{\circ} \mathrm{C}\right]$. The mean annual rainfall is $800 \mathrm{~mm}$ with a dry cold season (DCS, June-September) and a humid warm season (HWS, DecemberMarch). The Ctalamochita River -also called 'Río Tercero'- is the main tributary, with a base flow of $0.5 \mathrm{~m}^{3} \mathrm{~s}^{-1}$ during the DCS, which is regulated by four dams located in the upland region (Lozada et al., 2015). The Ctalamochita River is an important source of drinking water for the city of Córdoba, electric power and also an important recreational area. On the other hand, residual effluents from industrial activities and sewage water from cities and villages (Table 1) are discharged into the river course.

\subsection{Sample collection and sample treatment}

Three samples of subsurface water $(0-10 \mathrm{~cm}, 1 \mathrm{~L})$ and two samples of sediment $(0-5 \mathrm{~cm})$ were taken from a batch of pooled samples collected in the DCS and HWS. Autochthonous aquatic plants (macrophyte Potamogeton pusillus) were collected from a pristine site of the Suquía watershed and acclimated for two weeks in aquariums (Bertrand et al., 2017). Afterwards, the plants ( $3 \leq \mathrm{n} \leq 7)$ were placed at the sampling sites in the DCS and left to stay for $96 \mathrm{~h}$ for metal uptake. Only the root tissue was considered for analysis. After collecting the samples, they were washed three times with ultrapure water, frozen with liquid 
Table 1

Characteristics of the principal cities located along the Ctalamuchita River.

\begin{tabular}{lll}
\hline City & Population (inh.) & Principal Activity \\
\hline Santa Rosa de Calamuchita & 12.220 & Tourism \\
Embalse & 8.500 & Tourism, nuclear power station, and hydroelectric energy production \\
Almafuerte & 11.220 & Tourism \\
Río Tercero & 46.250 & Metal, food industry, tanneries, and chemical industries \\
Villa María & 79.900 & Retail, agriculture and dairy industry \\
Bell Ville & 34.400 & Services, trade, and industry \\
\hline
\end{tabular}
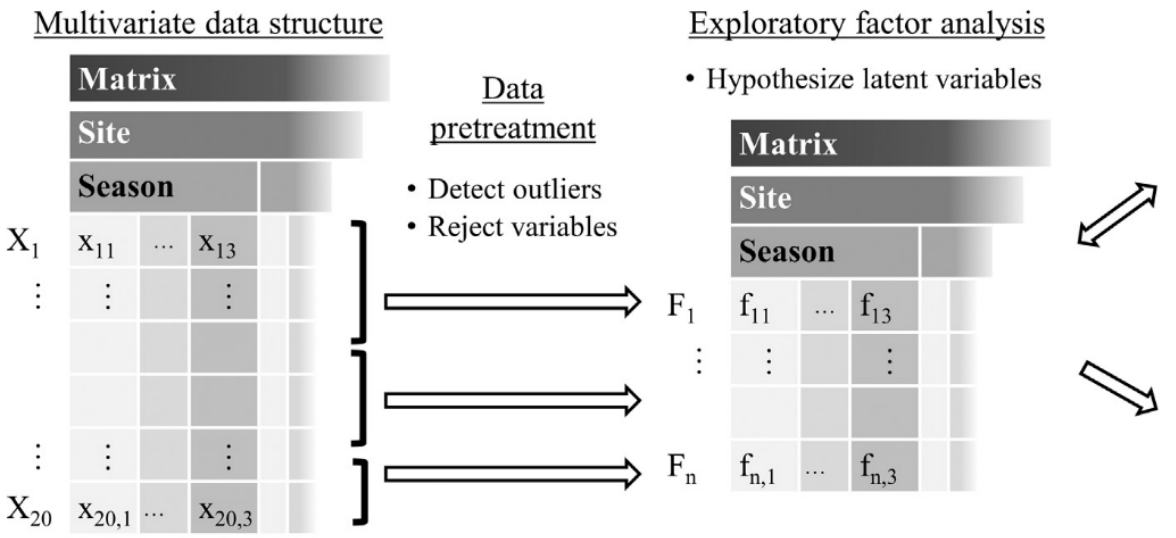

\section{$\underline{\text { Structural equation modeling }}$}

- Confirm latent variables

- Establish relationship between matrixes

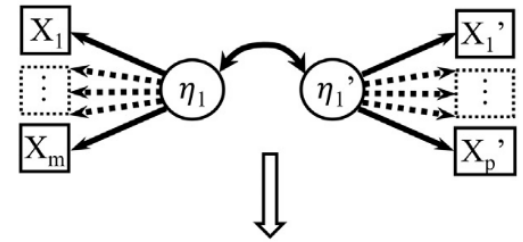

\section{Multilevel modeling}

- Identify and confirm spatio-temporal trends

$$
\log \left(\mu_{i j}\right)=\left(\beta_{0}+u_{j}\right)+\beta_{1} S+\epsilon_{i j}
$$

Fig. 2. Flowchart with the statistical methods implemented.

nitrogen and kept at $-80{ }^{\circ} \mathrm{C}$ until analysis. In the laboratory, the water samples were acidified with concentrated suboiling $\mathrm{HNO}_{3}$ to a final concentration of $2 \%$ and then filtered $(0.45 \mu \mathrm{m})$. The sediments $(1 \mathrm{~g})$ were digested with aqua regia $\left(\mathrm{HNO}_{3:} \mathrm{HCl} ; 1: 3\right)$ to determine the pseudo-total element content in the $<63 \mu \mathrm{m}$ sediment fraction according to Maiz et al. (1997). The metals in the root were extracted according to Chappaz et al. (2012). Briefly, the samples were dried at $38^{\circ} \mathrm{C}$ (constant weight) and grounded in a mortar. Afterwards, they were digested in Teflon tubes containing aqua regia at $160^{\circ} \mathrm{C}$, filtered through a $0.45 \mu \mathrm{m}$ nitrocellulose membrane, and stored at $4{ }^{\circ} \mathrm{C}$ until analysis.

\subsection{Analysis of physical, chemical and microbiological variables}

Inorganic constituents in surface water were analyzed in the DCS and HWS, considering international reference methods (APHA, 2005). The analysis included inorganic constituents (chloride: $\mathrm{Cl}^{-}$, sulfate: $\mathrm{SO}_{4}{ }^{2-}$, nitrite: $\mathrm{NO}_{2}{ }^{-}$, dissolved oxygen: DO, ammonium: $\mathrm{NH}_{4}{ }^{+}$and total phosphorous: TP), physicochemical properties $(\mathrm{pH}$, temperature: $\mathrm{T}$, and conductivity: Cond) and total coliforms (TC). The metals and metalloids were analyzed in surface water, sediments and root tissue, and they included: boron (B), aluminum ( $\mathrm{Al}$ ), vanadium (V), chromium $(\mathrm{Cr})$, manganese $(\mathrm{Mn})$, iron (Fe), cobalt $(\mathrm{Co})$, nickel $(\mathrm{Ni})$, copper $(\mathrm{Cu})$, Zinc $(\mathrm{Zn})$, arsenic (As), selenium (Se), rubidium (Ru), strontium ( $\mathrm{Sr}$ ), molybdenum (Mo), silver (Ag), cadmium (Cd), barium (Ba), mercury $(\mathrm{Hg})$ and lead $(\mathrm{Pb})$. The analysis was performed with an inductively coupled plasma mass spectrometry (ICP-MS, Agilent Technology $7500 \mathrm{cx}$ ) equipped with an auto-sampler ASX-100 (CETAC Technologies, USA).

\subsection{Reagents, quality assurance and quality control}

The analytical grade reagents were supplied by Sigma-Aldrich (Germany), Merck (Germany) and Sintorgan (Argentina). The glassware was cleaned with ultrapure reagents to avoid contamination of samples during treatment (Monferrán et al., 2011). Standard solutions (AccuStandard, USA) were used for the calibration procedure. The limit of detection (LD) of the instrument for the different metals ranged from 0.02 to $8.2 \mu \mathrm{g} \mathrm{L}^{-1}$ in surface water, from 0.01 to $1.8 \mu \mathrm{g} \mathrm{g}^{-1}$ in sediments and from 0.15 to $0.80 \mu \mathrm{g} \mathrm{g}^{-1}$ in root tissue. The concentration of the studied elements was measured in triplicate. Metal recovery was higher than $90 \%$ in all cases.

\subsection{Data treatment prior to analysis}

Data pretreatment for multivariate analysis was performed according to Olsen et al. (2012). Briefly, metals and metalloids with fraction of non-detects larger than $50 \%$, including measurements below the quantification limit, were excluded from the analysis. Otherwise, concentrations below the quantification limit were substituted by the corresponding detection limit. Anomalous observations (multivariate outliers) were identified by biplot analysis based on Mahalanobis distance and by using boxplots (Manly and Navarro Alberto, 2017). Pairwise correlations were calculated with Spearman correlation coefficients. In addition, sampling adequacy for PC-FA was measured with the Keiser-Meyer-Olkin-KMO coefficient after data standardization, and the multivariate correlation was tested with Bartlett's test for sphericity.

\subsection{Statistical analysis}

Regarding metals and metalloids, PC-FA was separately applied to each environmental matrix to understand spatial and temporal variability. Fig. 2 shows the sequence of the statistical analysis used in this study. Another PC-FA was conducted for inorganic constituents, physicochemical properties and total coliforms in surface water. A sensitivity analysis was carried out with and without single variables. The number of factors to be retained was determined by using Horn's parallel factor analysis. This method estimates the sample bias for calculated eigenvalues from a randomly generated dataset of the same size as the observed dataset (Dinno, 2009). An orthogonal axis rotation (varimax) with Kaiser normalization was performed to differentiate the loadings of variables contributing to the retained factors. A factor loading value higher than 0.7 was considered for the interpretation of factors and the assignment of the new dimensions. The numeric values 
of each factor corresponding to each measurement (scores) were calculated and treated as observations of latent variables (new variables). Those 'hypothetical constructs' will be considered as indirectly measured by the observed variables $X_{k}$. The analyses were carried out with Stata $($ ) version 2014.

\subsection{Statistical modeling}

A multilevel approach was adopted considering repeated measurements nested into sites. The two-level model was chosen to explore latent variable trends over time for each environmental matrix taking (Eq. (1)):

$\log \left(\mu_{i j}\right)=\left(\beta_{0}+u_{j}\right)+\beta_{1} S+\epsilon_{i j}$,

where $E\left(L_{i j}\right)=\mu_{i j}$ (expected value) and S represented the seasonal effect (DCS as baseline). The lineal predictor (right term) is composed of a fixed part $\left(\beta_{0}+\beta_{1} S\right)$, which includes an intercept $\left(\beta_{0}\right)$ representing the expected value of the new dimension, and a regression coefficient $\left(\beta_{1}\right)$ associated with the seasonal dummy variable; a random part $\left(u_{j}\right)$ that represents the $\mathrm{j}^{\text {th }}$ site random intercept (level 2) and a random component $\left(\epsilon_{i j}\right)$ corresponding to the $i^{\text {th }}$ measurement of $j^{\text {th }}$ site (level 1 ). The response variable $\left(L_{i j}\right)$ corresponds to the scores along the sites and is linked to the linear predictor by the log function. The Gaussian and gamma distributions were selected for the response variable distribution. Akaike's information criteria (AIC) and the unexplained residual variance were used for modeling selection. A three level model including two random intercepts was assessed in order to account for a potential upstream-downstream relationship. This model did not improve the performance obtained in the previous (two level) model (data not shown). In order to measure the correlation between individual observations of the same group, the absolute-agreement intra-class correlation coefficient $\left(\rho_{1}\right)$ was calculated as follows (McGraw and Wong, 1996):

$\rho_{1}=\operatorname{ICC}_{(1)}=\frac{\sigma_{u}^{2}}{\sigma_{u}^{2}+\sigma_{\epsilon}^{2}}$,

where $\sigma_{u}^{2}$ is the variance corresponding to random term and $\sigma_{\epsilon}^{2}$ the variance at level 1 . The $\rho_{1}$ coefficient expresses how much of the total variability is explained by groups, taking values from zero to one. The higher the $\rho_{1}$ value, the higher the variance explained by groups and the higher the reliability of measurements. The $\rho_{1}$ coefficient was not calculated in macrophyte due to unbalanced data.

The exploratory PC-FA was further confirmed by using SEM. The standardized variables selected for the SEM analysis were those that contributed most to each dimension from FA (factor loading higher than 0.7). Prior to SEM analysis, the normality assumption of standardized variables was verified by using the Dornik-Hansen test. This technique allows for a graphic representation of the hypothesized model by connecting measured variables and latent variables with arrows (path diagrams). In addition, SEM provides a clearer conceptualization of the model structure. Furthermore, relations among latent variables can be modeled and tested. Consequently, SEM was used to confirm exploratory PC-FA and to estimate the association structure of the most important latent variables of surface water and sediment. The two-dimensional factor model, corresponding to the left part of the diagram in Fig. 7a), can be formulated as:

$\boldsymbol{y}_{k}=\beta+\Lambda_{y} \eta_{k}+\epsilon_{k}$,

where $\boldsymbol{\beta}$ is a vector of constants, $\boldsymbol{\Lambda}_{\mathrm{y}}$ is a factor loading matrix, $\boldsymbol{\eta}_{\mathrm{k}}$ a vector of two common factors with a covariance matrix $\Psi$ and $\epsilon_{\mathrm{k}}$ a vector of unique factors with a diagonal covariance matrix $\Theta$. The values taken by $\boldsymbol{\eta}_{\mathrm{k}}$ factor are represented by $\mathrm{L}_{\mathrm{ij}}$ in the two-level model (Eq. (1)). The covariance matrix of the responses takes the form:

$\Omega=\beta+\Lambda_{y} \Psi \Lambda_{y}^{\prime}+\Theta$.
The expanded form of Eq. (3) is presented in Appendix A (Eq. A.1).

\section{Results and discussion}

\subsection{Data treatment prior to $P C-F A$}

Regarding metals and metalloids, the analysis did not include four variables in surface water (selenium, silver, cadmium and mercury), one variable in sediment (boron) and five variables in root of macrophyte (boron, selenium, molybdenum, silver and cadmium, more than $50 \%$ of non-detects). In addition, two macrophyte measurements were not considered because they were not reliable according to Mahalanobis biplots and boxplots (listwise deletion). The KMO values were $0.59,0.57$ and 0.70 for surface water, sediment and macrophyte, respectively. Bartlett's test for sphericity indicated that reduction of dimensionality would be achieved by factor analysis $(p<0.001)$. Moreover, pairwise correlations between metal and metalloid variables of the same matrix showed that more than 35 pairs of variables were highly correlated. The highest correlations were obtained between iron, cobalt and aluminum in all matrices (values around 0.8 for surface water and sediment, and around 0.7 for macrophyte, $p<0.01$ ). Similar results were obtained for physicochemical properties and inorganic constituents (KMO $=0.51$, Bartlett test: $p<0.001$ ), with high correlation coefficients for chloride, sulfate and conductivity (values around $0.9, p<0.001$ ). Thus, reduction of dimensionality after PC-FA is expected for both groups of variables.

\subsection{Exploratory PC-FA}

According to Horn's parallel factor analysis, two or four factors should be retained (please see Tables A.4-6 for eigenvalues and cumulative variance). Two factors (F1, F2) were retained to explore the relationship among the most important dimensions of different matrices. Sensitivity analyses led to the same constructs.

\subsubsection{Physical, chemical and microbiological parameters in surface water}

The first two factors accounted for $71 \%$ of variability. The F1 was associated with conductivity, chloride and sulfate (Fig. 3). Both ions might come from natural and anthropogenic sources. Dissolution of mineral rocks, runoff from agricultural fields with intensive fertilizer use (e.g. $\mathrm{KCl}, \mathrm{FeSO}_{4}$ ), contribute to increasing concentrations in streams (van der Perk, 2014). Moreover, conductivity is a measure of ionic species in solution. $\mathrm{F} 1$ thus represented the soluble ions in surface water and it was named Salinity. Similarly, the important variables for F2 representation were nitrogen-containing ions (mainly nitrite), deficiency of dissolved oxygen and total coliforms. Ammonium ion is produced by oxidation of nitrogen-containing molecules and is further oxidized to produce nitrite and nitrate during the nitrification process, which involves oxygen consumption.

The coliform group is used as criterion of water suitability for domestic and industrial use and it might be related to fecal pollution. Therefore, F2 was named Organic waste, considering that it represented waste water and sewage sludge sources. Vega et al. (1998) also reported a similar assignment of the first two principal components, which characterized natural sources (chloride, conductivity, hardness, etc.) and anthropogenic sources (organic matter, nitrogen and phosphorous), respectively.

The groundwater recharge area is located mainly in the highland region and discharge of groundwater increases towards the city of Bell Ville in the eastern region (Blarasin et al., 2014). Then, freshwater flows from the highland region and Salinity increases downstream as a consequence of surface runoff from agricultural areas in the middle and lowland region (Fig. 3). In addition, Salinity raised dramatically at S7 as a result of groundwater discharge. Regarding seasonal variations, a higher rainfall frequency and a warmer temperature enhance ion dissolution (Canfield, 1997). Thus, the largest difference in Salinity was 


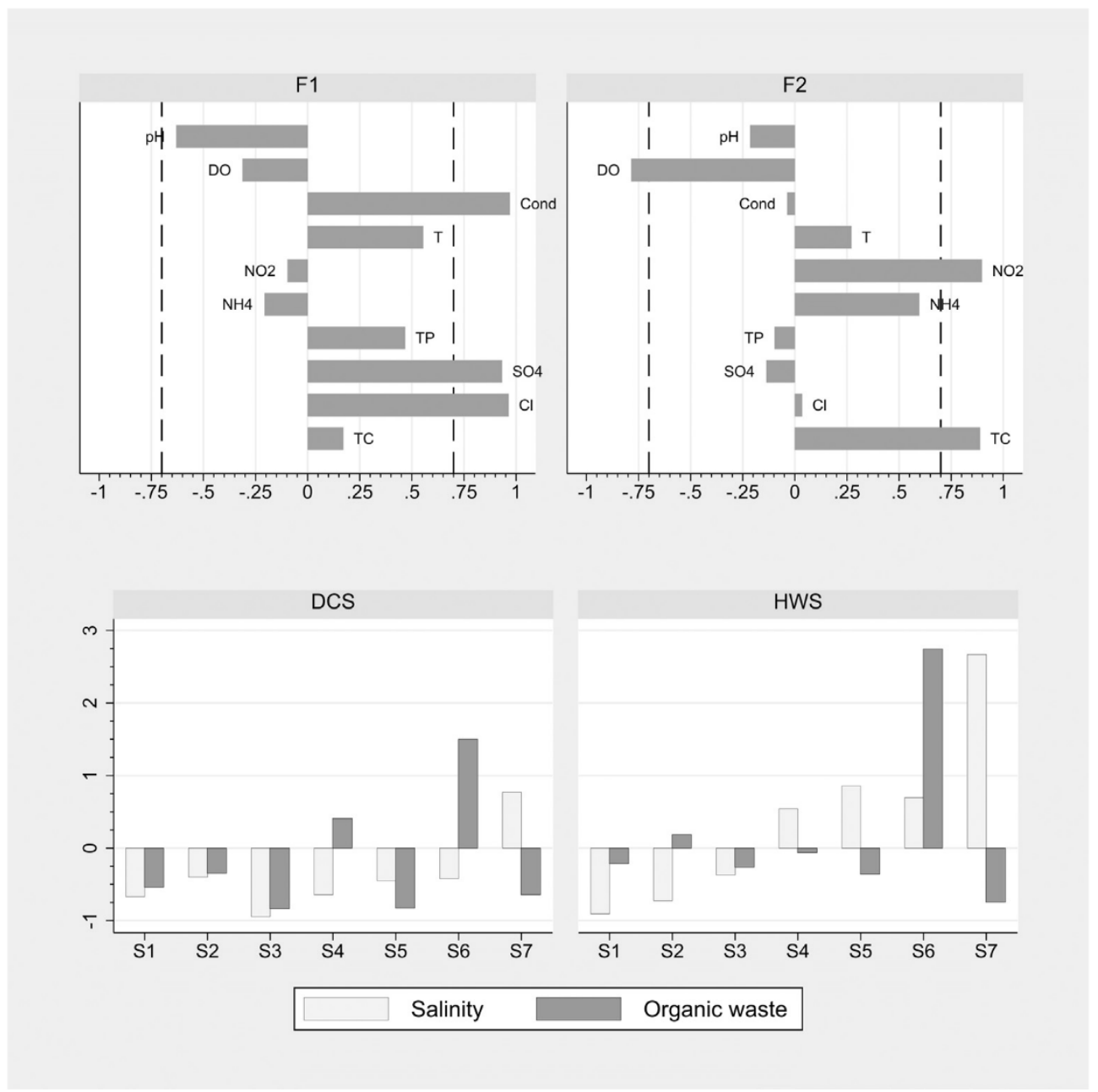

Fig. 3. Factor loadings (F1 and F2) for physicochemical properties of surface water and scores of Salinity and Organic waste for sampling sites in the DCS and HWS.

observed for distant sites (S1 and S7) in the HWS, where conductivity and chloride content were increased by a factor of 13.3 and 24.3 , respectively. On the other hand, Organic waste exhibited a jagged behavior (Fig. 3). Water quality was hence degraded in sites downstream of cities as a consequence of municipal sewage discharge. Afterwards, water quality was partially restored due to self-purification of surface waters. Larger variations in Organic waste scores occurred in sampling sites next to cities with larger populations (Fig. 1). Note that the sampling site downstream of the city of Villa María registered the highest levels in total coliforms in the HWS $\left(3,150,000 \mathrm{CFU} 100 \mathrm{~mL}^{-1}\right)$, exceeding suggested limits for safe recreational waters $(10,000 \mathrm{CFU}$ $100 \mathrm{~mL}^{-1}$; WHO, 2003).

\subsubsection{Metals and metalloids in surface water}

Similarly, the first two factors accounted for $65 \%$ of variance. F1 was represented by rubidium, vanadium, aluminum, iron, boron, cobalt, arsenic, barium, molybdenum and strontium (Fig. 4). F1 included the most abundant elements in the earth's crust (aluminum and iron), which represented in some sampling sites up to $49 \%$ and $68 \%$ of the total metals and metalloid concentration in the DCS and HWS, respectively. In addition to alkaline metals (rubidium, strontium and barium), F1 also included highly oxidized trace elements, which are usually present in natural surface waters as oxyanions (arsenic, boron, vanadium and molybdenum). High concentrations of vanadium, arsenic and boron in surface waters are derived from natural sources, namely thermal springs and volcanic ashes (Hem, 1985). Some authors reported the occurrence of arsenic, vanadium and molybdenum in groundwater of the middle-eastern region of Córdoba, mainly explained by the presence of loess rich in volcanic components (Matteoda and Blarasin, 2016; Nicolli et al., 1989). Moreover, F1 involved most of the variables analyzed, which accounted for [94-97\%] of the total concentration in the DCS and HWS, respectively. Thus, F1 represented the natural contribution of metals and metalloids to surface waters and it was named Geological elements.

The spatial trend in the scores of Geological elements showed a sustained increase from the upland to the lowland region (Fig. 4). Two particular patterns were observed within the group of Geological elements. The major contributing metals (aluminum and iron) increased their concentration downstream in the watershed as far as S6 and a reduction was observed at $\mathrm{S7}$. At the same time, there was a sharp rise in vanadium, arsenic, molybdenum and strontium concentration (Tables A.1, A.2 and A.3). Thus, an inflow of groundwater into the stream at S7 sustained the increase in the scores of Geological elements. Therefore, Geological elements represent two main sources of metals and metalloids of hydrologic origin, namely surface runoff in the highland and midland region and groundwater discharge in the lowland region. The tendency of increasing scores downstream from S1 was interrupted at S3 (Fig. 4). The long residence time of water in lakes and dams causes fine particles to settle through the water column. In addition, Varol (2013) observed a reduction in metal concentration from the entrance of the stream to the dam wall in three-dam reservoirs in the Tigris River basin, Turkey. Therefore, the removal of metals in Rio Tercero dam (upstream S3) might have taken place by sedimentation of fine particles or other processes associated with lentic environments (Salomons and 


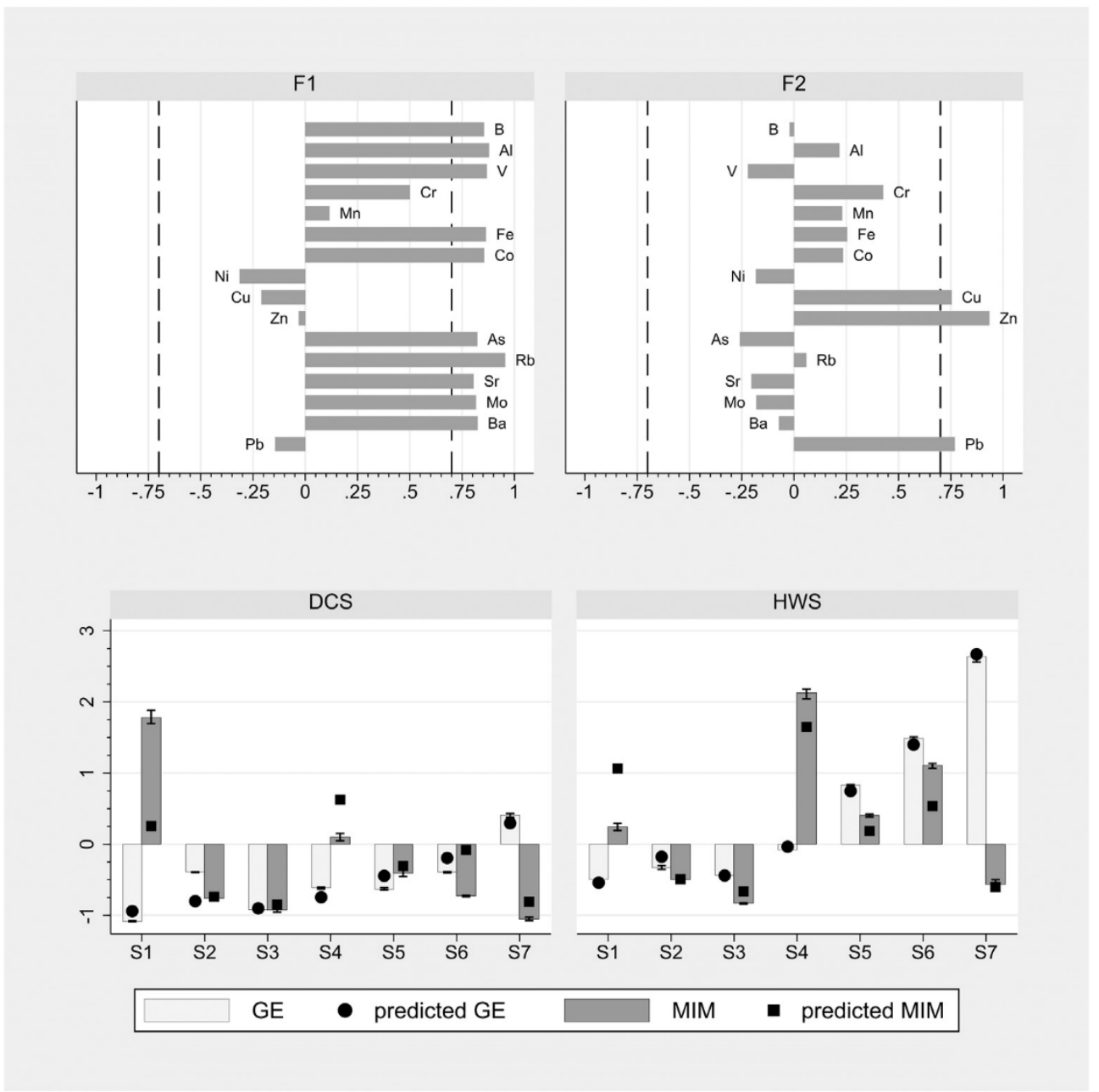

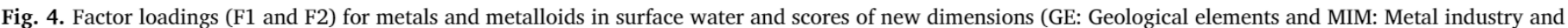

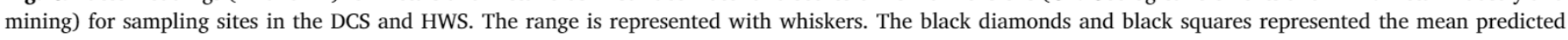
values.

\section{Forstner, 1984).}

F2 chiefly explained the shared variability of zinc, lead and copper. These metals are usually associated with anthropogenic sources. Zinc is widely used in the steel industry for zinc-iron protective coatings, while copper is mainly used in wiring, electronics circuits and plumbing. Other uses of copper include healthcare (bactericides) and pesticide manufacturing (fungicides and algaecides). Lead is used for manufacturing batteries, ammunition and ceramics, and as a paint pigment (Wuana and Okieimen, 2011). Moreover, leaching and runoff from tailing dumps in mining areas are also sources of metal pollution. In this sense, copper and lead-zinc mining activities were formerly developed in the upland region of the Ctalamochita River (1920-1950, Mutti et al., 2005). Therefore, F2 represented Metal industry and mining.

The scores of Metal industry and mining showed maximum values at S1 and S4 (Fig. 4). From there on, a reduction trend was observed downstream in both seasons due to a dilution of metal concentration with water of better quality. The abandoned mines located in the eastern region of the cities of Santa Rosa de Calamuchita and Río Tercero are the major anthropogenic sources of metals upstream in S1 and S4, respectively (Fig. 1). The city of Río Tercero concentrates important metallurgical and petrochemical industries, armament and ammunition production, the manufacturing of machinery and components for agriculture, and building and mining activities. Therefore, a remarkable increase in $\mathrm{Zn}$ and $\mathrm{Pb}$ concentration (4.9 and 3.5 times, respectively) was observed from S3 to 54 . Both dimensions showed similar patterns in the DCS and HWS (Fig. 4).

\subsubsection{Metals and metalloids in sediment}

The first and second factor explained $36 \%$ and $28 \%$ of the shared variability. For the first one, large loads were obtained for vanadium, arsenic and di- and trivalent cations, namely copper, nickel, cobalt, iron and aluminum (Fig. 5). The decreasing tendency of scores from S1 to S7 in both seasons represented a reduction of $15 \%$ and $28 \%$ in iron and aluminum content, respectively, coupled with an increment of $75 \%$ in arsenic sediment concentration. On the other hand, F2 represented lead, cadmium, selenium, zinc and silver. Increments in sediment concentration were observed for $\mathrm{Zn}$ and $\mathrm{Pb}$, whose levels increased 4.9 and 1.6 times from S3 to S4, respectively. Both factors resembled the variables associated with the first two factors obtained for surface water. The mineral composition of rocks or sediments is not strictly related to the dissolved elements in the water column, but with the less stable or highly soluble fraction (Hem, 1985). Then, a perfect match was not expected between shared variables of the two most important factors of different matrices. Therefore, the new dimensions, also named Geological elements and Metal industry and mining, described the same process and sources for surface water and sediment.

The scores of Geological elements in sediment showed an inverse relationship compared to surface water, whereas those of Metal industry and mining reflected to some extent a similar tendency in both matrices along the watershed. Then, the concentration of metals and metalloids in surface water and sediments in the Geological elements group would be oppositely affected by seasonal variations, whereas those of surface water in the Metal industry and mining group might condition 


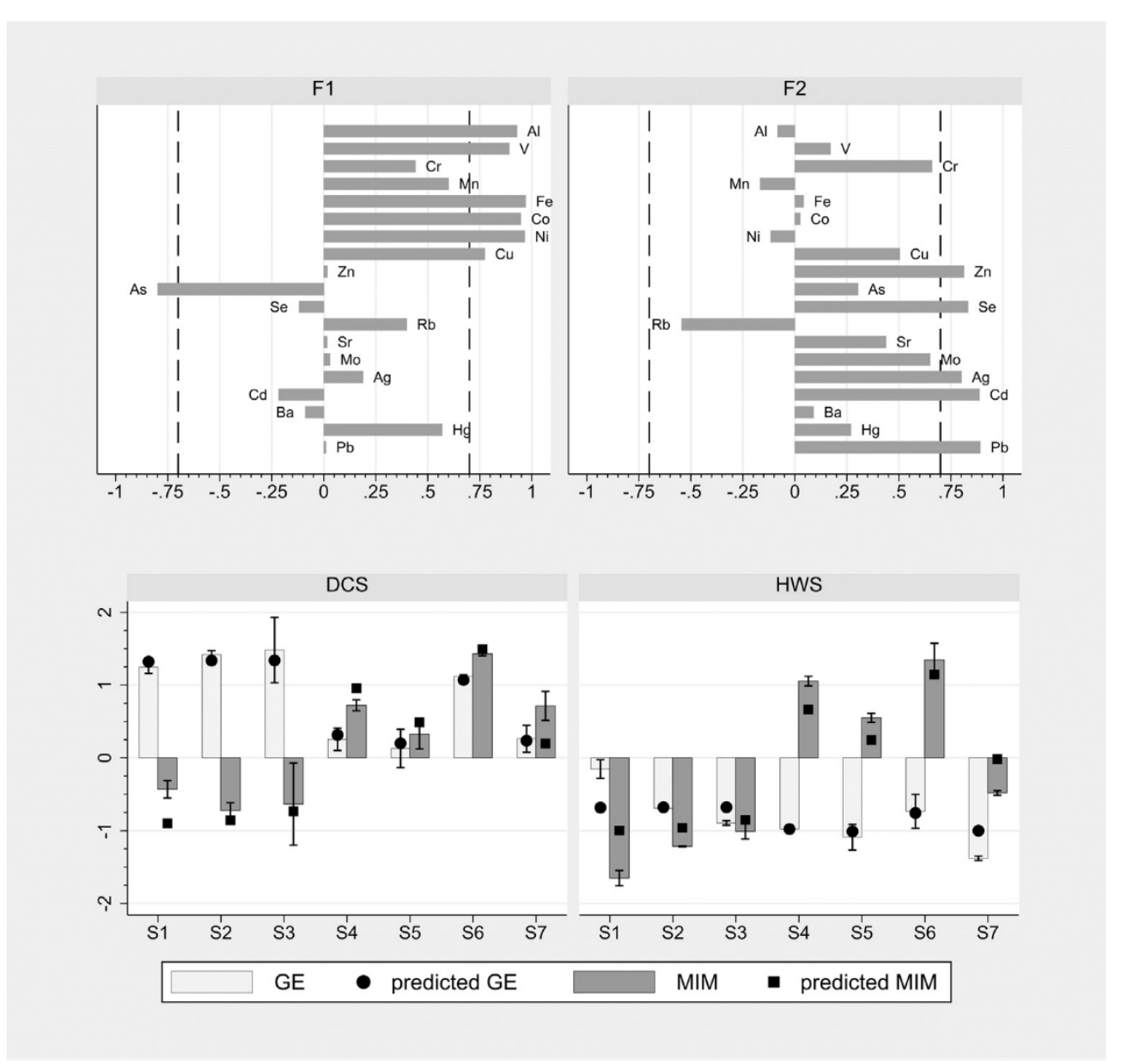

Fig. 5. Factor loadings (F1 and F2) for metals and metalloids in sediment and scores of new dimensions (GE: Geological elements and MIM: Metal industry and mining) for sampling sites in DCS and HWS. The range is represented with whiskers. The black diamonds and black squares represented the mean predicted values of the mixed effect model.

concentration in sediment. These assumptions will be tested by using SEM analysis (Section 3.4).

\subsubsection{Metals and metalloids in root of macrophytes}

The first two factors explained $62 \%$ of the shared variability. F1 was represented by cobalt, vanadium, iron, arsenic, barium and strontium, and F2 by lead, zinc, chromium and nickel (Fig. 6). Nickel is also used by industries in making various steels, alloys and in electro plating; chromium compounds are used in chrome plating, as pigment additives, leather tanning and wood treatment (van der Perk, 2014). As well as surface water, F1 and F2 involved similar sets of variables and thus similar representations (Geological elements and Metal industry and mining). However, differences in Metal industry and mining variables between surface water and macrophyte roots might be attributable to seasonal variations of metal discharges from anthropogenic sources. In addition, a separate PC-FA for surface water only with DCS dataset revealed that chromium and nickel were important variables in the shared variance of F2.

Geological elements showed increasing scores from the highland to midland region, similarly to surface water (Fig. 6). However, the root tissue showed lower scores in the lowland region. The scores of Metal industry and mining registered a maximum value at S4, reflecting the metal source upstream (city of Río Tercero). The trend observed for surface water was not clearly represented by the scores of macrophytes for Metal industry and mining. Metal and metalloid uptake depends not only on the dissolved analyte concentration but also on the physicochemical properties of the aquatic environment (salinity, $\mathrm{pH}$, temperature, etc.), which condition absorption and transport processes (Luoma and Rainbow, 2005). Hence, the root of macrophyte Potamogeton pusillus failed to correctly represent the dimensions along the watershed and showed higher within-site variance compared to surface water and sediment matrices.

By using the combined exploratory technique, PC-FA, we grouped variables and tracked sources of pollution (metal industries, sewage discharges and former mining activities). Compared to PCA alone, PCFA is a more suitable technique to highlight the latent variables dealing with underlying processes responsible for surface water quality. On the other hand, PCA - based on orthogonal linear transformation of a set of variables optimizing a certain algebraic criterion - does not involve an explicit model (Jolliffe, 2002). Then, FA enables the researcher to hypothesize a specific number of unobservable factors or latent variables to be sought. In this study, natural and anthropogenic contributions to physicochemical properties and metals and metalloids in surface water were clearly separated in the first two factors. The variables grouped in F1 were associated with runoff process and groundwater discharge in the Ctalamochita River.

\subsection{Multilevel modeling}

The Gaussian distribution was chosen for the new response variables (Geological elements and Metal industry and mining score) considering the lower AIC values and a suitable performance in predicting higher values of the response variable. The predicted values of outcomes for surface water and sediment were close to the mean scores (Fig. 4 and Fig. 5). The random term of model (sites) accounted for a significant variance of Geological elements and Metal industry and mining for surface water and sediment samples ( $p<0.05$, Table 2). Also, ICC values were close to unity (Table 2), indicating that the between-site variances of the latent variables were greater compared to the withinsite variances for these matrices (eq. (2)). Furthermore, a higher 


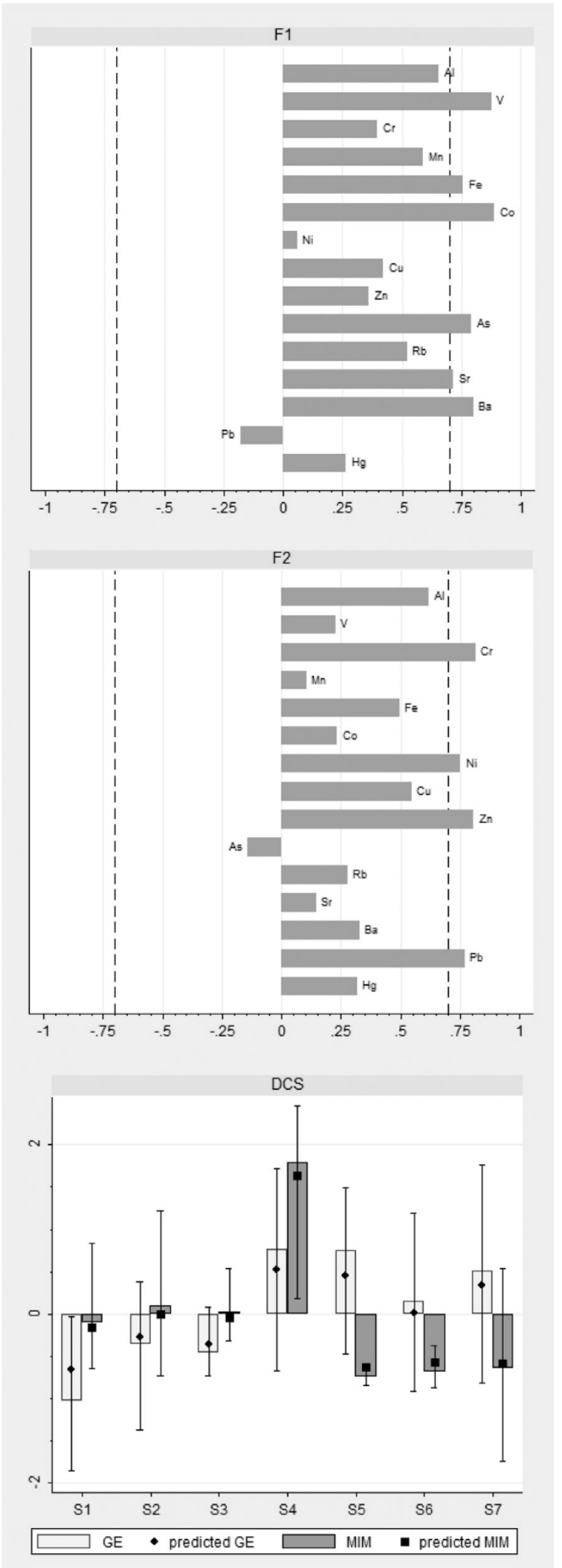

Fig. 6. Factor loadings (F1 and F2) for metals and metalloids in root of macrophyte and scores of new dimensions (GE: Geological elements and MIM: Metal industry and mining) for sampling sites in the DCS. The range is represented with whiskers. The black diamonds and black squares represented the mean predicted values of the mixed effect model.
Table 2

Estimates (standard error) of random (variance) and fixed effects (season) for surface water and sediment latent variables and intra-class correlation coefficients for dry cold season (DCS) and humid warm season (HWS).

\begin{tabular}{llllll}
\hline Matrix & $\begin{array}{l}\text { Response } \\
\text { variable: } L_{i j}\end{array}$ & $\begin{array}{l}\text { Random effect: } \\
\operatorname{Var}\left(\mathrm{u}_{\mathrm{j}}\right)\end{array}$ & $\begin{array}{l}\text { Fixed effect: } \\
\exp \left(\beta_{1}\right)\end{array}$ & DCS & HWS \\
\hline \multirow{2}{*}{ Surface water } & $G E$ & $0.384(0.209)^{\mathrm{a}}$ & $2.597(0.134)^{\mathrm{c}}$ & 0.9996 & 0.9996 \\
& MIM & $0.487(0.354)^{\mathrm{a}}$ & $1.566(0.248)^{\mathrm{b}}$ & 0.9991 & 0.9992 \\
Sediment & GE & $0.060(0.037)^{\mathrm{a}}$ & $0.291(0.034)^{\mathrm{c}}$ & 0.8664 & 0.8986 \\
& MIM & $0.256(0.157)^{\mathrm{a}}$ & $0.896(0.075)$ & 0.9077 & 0.9916
\end{tabular}

P-values corresponding to likelihood ratio test-LRTest assuming only fixed effects in baseline model were lower than 0.01 .

a: $p<0.05$; ${ }^{\text {b }} p<0.01$; $^{\mathrm{c}}: p<0.001$.

heterogeneity was observed for repeated measurements of sediment compared to surface water (lower sediment ICC values, $p<0.05$ ). Regarding the fixed-effect coefficient of season variables, significant effects were also observed in both matrices, with an increment of 2.6 times in the scores of Geological elements from the DCS to HWS for surface water. Metals related with surface runoff registered the greatest rise in concentration from the DCS to HWS (iron and aluminum: 5.5 and 4.7 times, respectively), compared to those associated with groundwater (arsenic and molybdenum: 1.77 and 1.41 times, respectively). The dissolved concentration of ionic species derived from rocks and mineral particles is strongly influenced by precipitation, runoff and temperature, which control the weathering rate (Canfield, 1997). After metal clean-up in the drainage basin during rainy periods, surface runoff transports the weathered material to the rivers, thus increasing metal concentration in surface waters (van der Weijden and Middelburg, 1989). Resuspension and oxidation of bottom sediments in the water column promote metal release in the soluble fraction (Calmano et al., 1993). Hence, the increment observed in surface water in the HWS should be related to a runoff process from nearby agricultural areas, as well as to metal and metalloid input from the finest sediment fraction. On the other hand, the fixed effect for Geological elements in sediment was significant and lower than unity (Table 2). Sediment erosion and transport occurs mainly during rainstorms in the rainy season (Smith et al., 2003). Also, seasonal variations of temperature in sediment and underlying water promote dissolution of metals by higher microbial activity (van den Berg et al., 2000). A reduction to 0.3 times in the scores was observed in the HWS compared to DCS, which accounted for a decrease of $14 \%$ in the most important variables contributing to this dimension. Also, Metal industry and mining showed an increment of 1.6 times for surface water in the HWS. Seasonal variations in hydrologic regimes might remarkably influence metal and metalloid concentration in surface water, leading to higher levels in the rainy season (Alves et al., 2014). Fluctuations in manufacturing production and industrial discharge might also have a season component affecting discharge of anthropogenic sources.

By using the multilevel modeling, we evaluated the significance of spatial and temporal variations of latent variables. The non-independence of site-repeated observations was properly accounted for by the random effect at the site level. The proposed model could be extended to simultaneously incorporate different catchments in the region, where the same variables are measured. Then, the addition of an extra random term would explain the variation among sites by nesting them within a certain catchment.

\subsection{Assessing surface water and sediment latent variables and their relationships with SEM}

The theoretical model is described in the path diagram (Fig. 7). The latent variables were represented with ovals (GE: Geological elements and MIM: Metal industry and mining) for each matrix (W: surface water, S: sediment). The straight arrows connecting the observed variables 

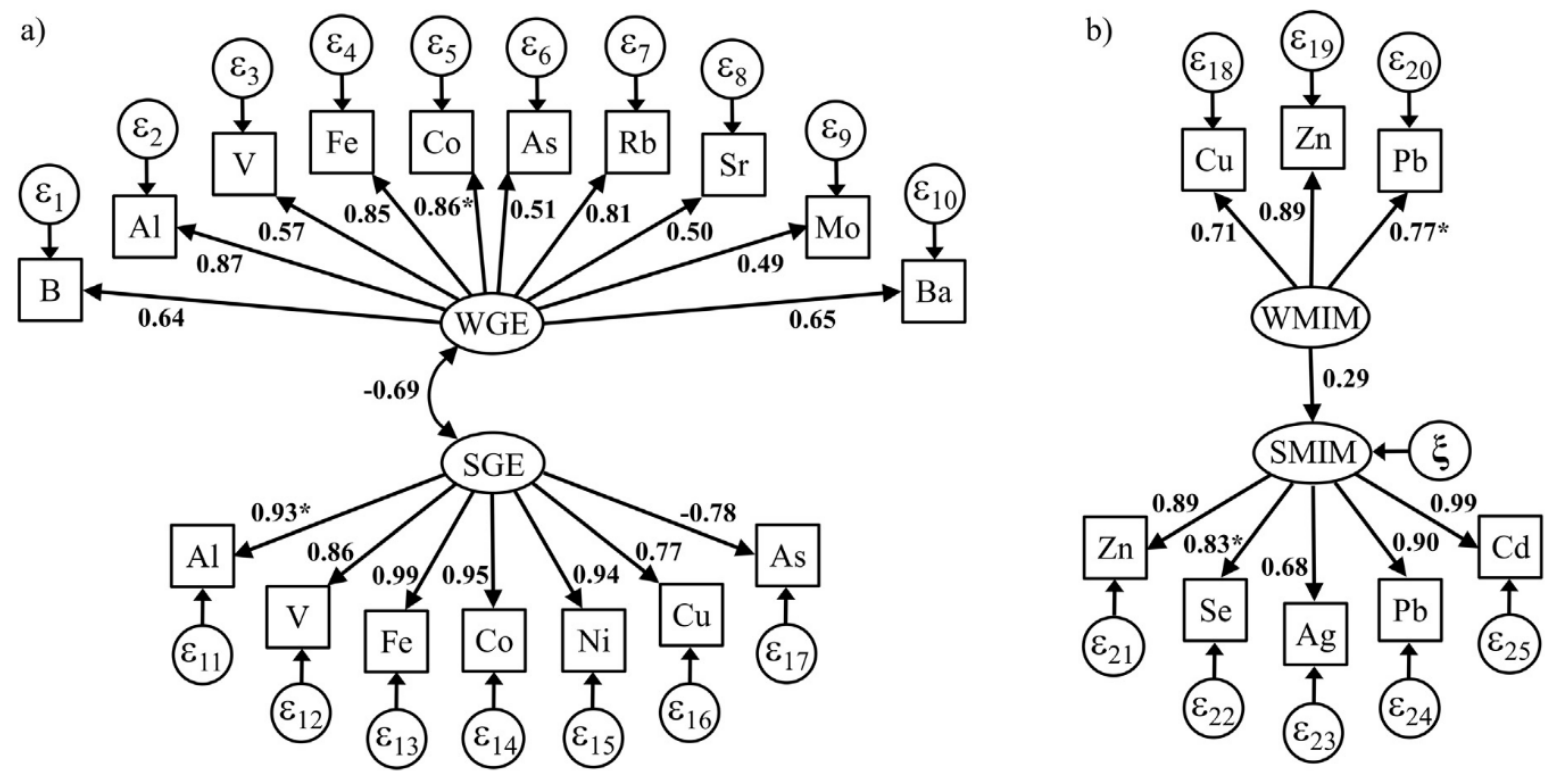

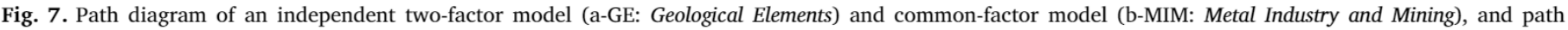

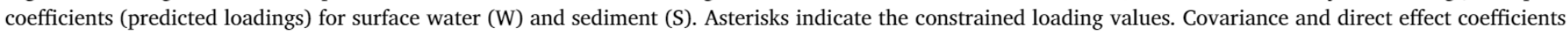
were indicated next to the arrows.

with latent variables represent linear relationship, and the curved double-headed arrow means correlation. The absence of arrows between latent variables indicates the assumption of independence (orthogonality). The residual of the observed variables were indicated with circles. First, one factor loading of each latent variable was constrained to fix the scale between loadings. The coefficients next to the arrows represented the predicted values after SEM analysis. Then, all the selected variables (factor loadings higher than 0.7 after PC-FA) contributed significantly to the latent variables $(p<0.001)$. The magnitude and direction of the parameter estimates are in accordance with the results obtained by FA, supporting the meaning and the name given to the latent variables. In addition, variables related to surface runoff obtained higher loadings than those elements associated with groundwater within the Geological elements group. A high significant correlation ( $p \leq 0.001$ ) was observed for Geological elements between matrices $\left(\rho=\operatorname{cov}_{(W G E, S G E)} /\left(\sigma_{W G E} \times \sigma_{S G E}\right)=-0.63\right)$. Hence, seasonal and spatial variation of factors influencing metal and metalloid concentration had an opposite effect on sediment and surface water, thus showing a negative covariance. In addition to the significant variation found between periods for Geological elements in surface water and sediment (Section 3.3-ML), the results obtained by SEM analysis indicate that spatial and temporal variations operate simultaneously on the inverse relationship of Geological elements between surface water and sediment. Sediment deposition is expected with the low-flow regime of the Ctalamochita River in the DCS, whereas sediment erosion will occur during the rainy season, thereby promoting a metal and metalloid increase in the HWS. The rise in metal and metalloid concentration in surface water would thus be due not only to runoff from agricultural surrounding areas, but also to a transfer from sediment to surface water in the HWS. Regarding Metal Industry and mining, a moderate significant direct effect of surface water on sediment was observed $(p \leq 0.05)$. Hence, discharge of metals into the Ctalamochita River conditioned to some extent their occurrence in sediment. Other authors have used SEM to model pollutant concentration in different organisms and to predict plankton blooms in a detailed conceptual model (Cao et al., 2017; Pollman, 2014; Wang et al., 2018). In this work, SEM was used to highlight the underlying factors - sources and processes - influencing the occurrence of metals and metalloids in the aquatic environment and to find a few substantive, meaningful paths between different matrices. The small number of samples analyzed was a strong limitation to establish further relationships in the model. Thus, no additional effort was made to conduct a specification search to accurately reproduce the covariance structure of the sample data and to obtain proper values for the goodness-of-fit indices of a saturated model (Fig. 7a-GE: $\chi^{2}=1268$, $\chi^{2}-$ degrees of freedom $=118, \mathrm{p}<0.001$, Standardized Root Mean Square Residual-SRMR $=0.18$; Fig. 7.b-MIM: $\chi^{2}=119, \chi^{2}-$ degrees of freedom $=19, \mathrm{p}<0.001$ Standardized Root Mean Square ResidualSRMR $=0.10$, see Table A.7 for more information; Schumacker and Lomax, 2004). From an exploratory PC-FA as a starting point, a basic model with SEM is proposed, which should be further improved in future research with complementary information.

\section{Conclusion}

The combination of PCA-FA with multilevel modeling and SEM has been a successful strategy to identify the underlying processes influencing the fate and transport of metals and metalloids in the Ctalamochita River Catchment. Based on the results obtained in this study, surface runoff and groundwater discharge were the processes that mainly contributed to the concentration of natural occurring elements (earth's crust elements). On the other hand, lead, zinc and copper-processing industries and old mining areas represented anthropogenic sources of point and diffuse pollution. Latent variables - representing hydrologic processes and anthropogenic sources - highlighted spatial and temporal variations in the catchment, in addition to the establishment of a degree of relationship between surface water and sediment. In this sense, an input of natural occurring elements into the Ctalamochita River was observed as a consequence of metal clean-up in the drainage basin and sediment resuspension during the warm-rainy season. Moreover, an inverse relationship was found between geological elements of sediment and surface water, indicating that the underlying processes affecting metal concentration operated oppositely in these matrices. Regarding anthropogenic sources, metal and metalloid discharges into the water body influenced directly the concentration in bottom sediments along the catchment.

This study is a first attempt to identify few substantive and meaningful paths between aquatic compartments. The combination of SEM with similar multilevel models, would be helpful in environmental studies dealing with spatial level or nested spatial scales and involving multiple matrices. The conceptual framework of the fate and transport 
of metals could be assessed in more detail in future studies by including additional information in a more complex SEM model, such as the measurement of metal and metalloids in other aquatic compartments, and baseflow and streamflow of the Ctalamochita River information to estimate seasonal metal fluxes.

\section{Declaration of interests}

The authors declare that they have no known competing financial interests or personal relationships that could have appeared to influence the work reported in this paper.

\section{Acknowledgments}

We would like to thank the National Scientific and Technical Research Council, Argentina (CONICET) for LL's fellowship. The present work is part of the $\mathrm{PhD}$ thesis of L. Bertrand, who also gratefully acknowledges fellowship from CONICET. We also wish to thank Dr. Daniel Wunderlin's suggestions that improved this article. This work was supported by grants from Agencia Nacional de Promoción Científica y Técnica, Argentina (FONCyT-PICT/; 2013-1348 and PICT 2015-1784), and Secretaría de Ciencia y Técnica, Universidad Nacional de Córdoba, Argentina (SECyT) UNC.

\section{Appendix A. Supplementary data}

Supplementary data to this article can be found online at https:// doi.org/10.1016/j.jhydrol.2019.03.019.

\section{References}

Alves, R.I.S., Sampaio, C.F., Nadal, M., Schuhmacher, M., Domingo, J.L., Segura-Muñoz, S.I., 2014. Metal concentrations in surface water and sediments from Pardo River, Brazil: human health risks. Environ. Res. 133, 149-155. https://doi.org/10.1016/j. envres.2014.05.012.

Amin, O., Ferrer, L., Marcovecchio, J., 1996. Heavy metal concentrations in litteral sediments from the Beagle Channel, Tierra del Fuego, Argentina. Environ. Monit. Assess. 41, 219-231.

Angelini, M.E., Heuvelink, G.B.M., Kempen, B., Morrás, H.J.M., 2016. Mapping the soils of an Argentine Pampas region using structural equation modelling. Geoderma 281, 102-118. https://doi.org/10.1016/j.geoderma.2016.06.031.

APHA, 2005. Standards Methods for the Examination of Water and Wastewater, 20th ed. American Public Health Association, Washington, DC.

Arribére, M., Guevara, S.R., Sánchez, R.S., Gil, M.I., Ross, R., Daurade, L.E., Fajon, V., Horvat, M., Alcalde, R., Kestelman, A.J., 2003. Heavy metals in the vicinity of a chloralkali factory in the upper Negro River ecosystem, Northern Patagonia, Argentina. Sci. Total Environ. 301, 187-203.

Avigliano, E., Schenone, N.F., Volpedo, A.V., Goessler, W., Fernández Cirelli, A., 2015. Heavy metals and trace elements in muscle of silverside (Odontesthes bonariensis) and water from different environments (Argentina): aquatic pollution and consumption effect approach. Sci. Total Environ. 506-507, 102-108. https://doi.org/10. 1016/j.scitotenv.2014.10.119.

Baroni, M.V., Wunderlin, D.A., 2017. Integrating data from Suquía River Basin: chemometrics and other concepts. In: Wunderlin, D.A. (Ed.), The Suquía River Basin (Córdoba, Argentina): An Integrated Study on Its Hydrology, Pollution, Effects on Native Biota and Models to Evaluate Changes in Water Quality. Springer International Publishing, Switzerland.

Beltrame, M.O., De Marco, S.G., Marcovecchio, J., 2009. Dissolved and particulate heavy metals distribution in coastal lagoons. A case study from Mar Chiquita Lagoon, Argentina. Estuar. Coast. Shelf Sci. 85, 45-56. https://doi.org/10.1016/j.ecss.2009. 04.027.

Benson, V.S., VanLeeuwen, J.A., Stryhn, H., Somers, G.H., 2007. Temporal analysis of groundwater nitrate concentrations from wells in Prince Edward Island, Canada: application of a linear mixed effects model. Hydrogeol. J. 15, 1009-1019. https:// doi.org/10.1007/s10040-006-0153-x.

Bertrand, L., Marino, D.J., Monferrán, M.V., Amé, M.V., 2017. Can a low concentration of an organophosphate insecticide cause negative effects on an aquatic macrophyte? Exposure of Potamogeton pusillus at environmentally relevant chlorpyrifos concentrations. Environ. Exp. Bot. 138, 139-147. https://doi.org/10.1016/j.envexpbot. 2017.03.006.

Blarasin, M., Cabrera, A., Matteoda, E., 2014. Aguas Subterráneas de la Provincia de Córdoba, 1ra ed. UniRío, Río Cuarto, Córdoba.

Bortey-Sam, N., Ikenaka, Y., Akoto, O., Nakayama, S.M.M., Asante, K.A., Baidoo, E., Obirikorang, C., Mizukawa, H., Ishizuka, M., 2018. Association between human exposure to heavy metals/metalloid and occurrences of respiratory diseases, lipid peroxidation and DNA damage in Kumasi, Ghana. Environ. Pollut. 235, 163-170. https://doi.org/10.1016/j.envpol.2017.12.005.

Calmano, W., Förstner, U., Hong, J., 1993. Mobilization and scavenging of heavy metals following resuspension of anoxic sediments from the Elbe river. In: Environmental Geochemistry of Sulfide Oxidation. American Chemical Society (ACS), pp. 298-321. https://doi.org/10.1021/bk-1994-0550.ch021.

Canfield, D.E., 1997. The geochemistry of river particulates from the continental USA major elements. Geochim. Cosmochim. Acta 61, 3349-3365. https://doi.org/10. 1016/S0016-7037(97)00172-5.

Cao, X., Wang, J., Liao, J., Gao, Z., Jiang, D., Sun, J., Zhao, L., Huang, Y., Luan, S., 2017. Bacterioplankton community responses to key environmental variables in plateau freshwater lake ecosystems: a structural equation modeling and change point analysis. Sci. Total Environ. 580, 457-467. https://doi.org/10.1016/j.scitotenv.2016.11. 143.

Chappaz, A., Lyons, T.W., Gordon, G.W., Anbar, A.D., 2012. Isotopic fingerprints of anthropogenic molybdenum in lake sediments. Environ. Sci. Technol. 10934-10940. https://doi.org/10.1021/es3019379.

Chowdhury, S., Mazumder, M.A.J., Al-Attas, O., Husain, T., 2016. Heavy metals in drinking water: occurrences, implications, and future needs in developing countries. Sci. Total Environ. 569-570, 476-488. https://doi.org/10.1016/j.scitotenv.2016.06. 166.

Demšar, U., Harris, P., Brunsdon, C., Fotheringham, A.S., McLoone, S., 2013. Principal component analysis on spatial data: an overview. Ann. Assoc. Am. Geogr. 103, 106-128. https://doi.org/10.1080/00045608.2012.689236.

Dinno, A., 2009. Exploring the sensitivity of horn's parallel analysis to the distributional form of random data. Multivar. Behav Res. 44, 362-388. https://doi.org/10.1080/ 00273170902938969.

FAO, 2016. website AQUASAT. Organ. las Nac. Unidas para la Aliment. y la Agric. URL http://www.fao.org/nr/water/aquastat/countries_regions/ARG/ (accessed 2.14.19).

Gagneten, A.M., Gervasio, S., Paggi, J.C., 2007. Heavy metal pollution and eutrophication in the lower Salado River basin (Argentina). Water Air Soil Pollut. 178, 335-349. https://doi.org/10.1007/s11270-006-9202-2.

Gaiero, D.M., Roman Ross, G., Depetris, P.J., Kempe, S., 1997. Spatial and temporal variability of total non-residual heavy metals content in stream sediments from the Suquia river system, Cordoba, Argentina. Water Air Soil Pollut. 93, 303-319. https:// doi.org/10.1023/A:1022113330970.

Griboff, J., Horacek, M., Wunderlin, D.A., Monferrán, M.V., 2018. Bioaccumulation and trophic transfer of metals, As and Se through a freshwater food web affected by antrophic pollution in Córdoba, Argentina. Ecotoxicol. Environ. Saf. 148, 275-284. https://doi.org/10.1016/j.ecoenv.2017.10.028.

Harguinteguy, C.A., Cofré, M.N., Fernández Cirelli, A., Pignata, M.L., 2016. The macrophytes Potamogeton pusillus L. and Myriophyllum aquaticum (Vell.) Verdc. as potential bioindicators of a river contaminated by heavy metals. Microchem. J. 124, 228-234. https://doi.org/10.1016/j.microc.2015.08.014.

Harguinteguy, C.A., Fernández Cirelli, A., Pignata, M.L., 2014. Heavy metal accumulation in leaves of aquatic plant Stuckenia filiformis and its relationship with sediment and water in the Suquía river (Argentina). Microchem. J. 114, 111-118. https://doi.org/ 10.1016/j.microc.2013.12.010.

Harguinteguy, C.A., Schreiber, R., Pignata, M.L., 2013. Myriophyllum aquaticum as a biomonitor of water heavy metal input related to agricultural activities in the Xanaes River (Córdoba, Argentina). Ecol. Indic. 27, 8-16. https://doi.org/10.1016/j.ecolind. 2012.11.018.

Hem, J.D., 1985. Study and Interpretation the Chemical of Natural of Characteristics Water, 3rd ed. US Geological Survey Water-Supply 2254.

Hwang, S.A., Hwang, S.J., Park, S.R., Lee, S.W., 2016. Examining the relationships be tween watershed urban land use and stream water quality using linear and generalized additive models. Water 8, 155. https://doi.org/10.3390/w8040155.

Jolliffe, I.T., 2002. Principal Component Analysis, 2nd ed., Springer Series in Statistics. Springer-Verlag, New York. doi: 10.2307/1270093.

Li, X., Zhang, Y., Guo, F., Gao, X., Wang, Y., 2018. Predicting the effect of land use and climate change on stream macroinvertebrates based on the linkage between structural equation modeling and bayesian network. Ecol. Indic. 85, 820-831. https://doi. org/10.1016/j.ecolind.2017.11.044.

Lozada, J.M.D., García, C.M., Herrero, H., Barchiesi, G.M., Romagnoli, M., Portapila, M., Lopez, F., Castelló, E., Cosavella, A., Brarda, J.P., 2015. Cuantificación del escurrimiento superficial de la cuenca del Río Carcarañá. Rev. Fac. CIENCIAS EXACTAS, FÍSICAS Y Nat. 2, 59-72.

Lu, Y., Song, S., Wang, R., Liu, Z., Meng, J., Sweetman, A.J., Jenkins, A., Ferrier, R.C., Li, H., Luo, W., Wang, T., 2015. Impacts of soil and water pollution on food safety and health risks in China. Environ. Int. 77, 5-15. https://doi.org/10.1016/j.envint.2014. 12.010.

Luoma, S.N., Rainbow, P.S., 2005. Why is metal bioaccumulation so variable? Biodynamics as a unifying concept. Environ. Sci. Technol. 39, 1921-1931. https:// doi.org/10.1021/es048947e.

Maiz, I., Esnaola, M.V., Millán, E., 1997. Evaluation of heavy metal availability in contaminated soils by a short sequential extraction procedure. Sci. Total Environ. 206, 107-115. https://doi.org/10.1016/S0048-9697(97)00223-4.

Manly, B.F.J., Navarro Alberto, J.A., 2017. Multivariate Statistical Methods, 4th ed. CRC Press, Taylor \& Francis Group, Boca Raton.

Marcovecchio, J., Botté, S., Severini, M.F., Delucchi, F., 2010. Geochemical control of heavy metal concentrations and distribution within Bahia Blanca estuary (Argentina). Aquat. Geochem. 16, 251-266. https://doi.org/10.1007/s10498-009-9076-1.

Matteoda, E.M., Blarasin, M., 2016. Elementos traza en aguas subterráneas. Córdoba. Argentina, in: XIII Congreso Latinoamericano de Hidrogeología. Mérida, México, pp. 469-476.

McGraw, K.O., Wong, S.P., 1996. Forming inferences about some intraclass correlation coefficients. Psychol. Methods 1, 30-46. https://doi.org/10.1037/1082-989X.1.1.30. 
Merlo, C., Abril, A., Amé, M.V., Argüello, G.A., Carreras, H.A., Chiappero, M.S., Hued, A.C., Wannaz, E., Galanti, L.N., Monferrán, M.V., González, C.M., Solís, V.M., 2011. Integral assessment of pollution in the Suquía River (Córdoba, Argentina) as a contribution to lotic ecosystem restoration programs. Sci. Total Environ. 409, 5034-5045. https://doi.org/10.1016/j.scitotenv.2011.08.037.

Monferrán, M.V., 2015. Metals and metalloids in water and sediment of the Suquía River basin: spatial and temporal changes. In: Wunderlin, D.A. (Ed.), The Suquía River Basin (Córdoba, Argentina): An Integrated Study on Its Hydrology, Pollution, Effects on Native Biota and Models to Evaluate Changes in Water Quality. Springer International Publishing, Switzerland, pp. 95-100 doi: 10.1007/698.

Monferrán, M.V., Galanti, L.N., Bonansea, R.I., Amé, M.V., Wunderlin, D.A., 2011. Integrated survey of water pollution in the Suquía River basin (Córdoba, Argentina). J. Environ. Monit. 13, 398-409. https://doi.org/10.1039/c0em00545b.

Monferrán, M.V., Garnero, P., De Los Angeles Bistoni, M., Anbar, A.A., Gordon, G.W., Wunderlin, D.A., 2016. From water to edible fish. Transfer of metals and metalloids in the San Roque Reservoir (Córdoba, Argentina). Implications associated with fish consumption. Ecol. Indic. 63, 48-60. https://doi.org/10.1016/j.ecolind.2015.11. 048.

Muse, J.O., Stripeikis, J.D., Fernández, F.M., D’Huicque, L., Tudino, M.B., Carducci, C.N., Troccoli, O.E., 1999. Seaweeds in the assessment of heavy metal pollution in the Gulf San Jorge, Argentina. Environ. Pollut. 104, 315-322.

Mutti, D., Di Marco, A., Tourn, S., Herrmann, C., Geuna, S., Caccaglio, O., González Chiozza, S., 2005. Evolución metalogenética de las Sierras Pampeanas de Córdoba y sur de Santiago del Estero: Ciclos Prepampeano y Pampeano. Rev. la Asoc. Geol. Argentina 60, 104-121.

Nicolli, H.B., Suriano, J.M., Peral Gomez, M.A., Ferpozzi, L.H., Baleani, O.A., 1989. Groundwater contamination with arsenic and other trace elements in an area of The Pampa, province of Cordoba, Argentina. RN - Environ. Geol. Water Sci. 14, 3-16.

Olsen, R.L., Chappell, R.W., Loftis, J.C., 2012. Water quality sample collection, data treatment and results presentation for principal components analysis - literature review and Illinois River watershed case study. Water Res. 46, 3110-3122. https:// doi.org/10.1016/j.watres.2012.03.028.

Pollman, C.D., 2014. Mercury cycling in aquatic ecosystems and trophic state-related variables - implications from structural equation modeling. Sci. Total Environ. 499, 62-73. https://doi.org/10.1016/j.scitotenv.2014.08.036.

Rabe-Hesketh, S., Skrondal, A., 2012. Multilevel and Longitudinal Modeling Using Stata, third. ed. Stata Press Publication, StataCorp LP, College Station, Texas.

Reckhow, K.H., Arhonditsis, G.B., Kenney, M.A., Hauser, L., Tribo, J., Wu, C., Elcock, K.J., Steinberg, L.J., Stow, C.A., McBride, S.J., 2005. A predictive approach to nutrient criteria. Environ. Sci. Technol. 39, 2913-2919. https://doi.org/10.1021/es048584i.

Rigacci, L.N., Giorgi, A.D.N., Vilches, C.S., Ossana, N.A., Salibián, A., 2013. Effect of a reservoir in the water quality of the Reconquista River, Buenos Aires, Argentina. Environ. Monit. Assess. 185, 9161-9168. https://doi.org/10.1007/s10661-0133243-y.

Ryan, P.B., Huet, N., MacIntosh, D.L., 2000. Longitudinal investigation of exposure to arsenic, cadmium, and lead in drinking water. Environ. Health Perspect. 108, 731-735 https://doi.org/sc271_5_1835 [pii] ET - 2000/08/31.

Sabater, S., Ginebreda, A., Barcelo, D., 2012. The Llobregat: The Story of a Polluted Mediterranean River, 1st ed. Springer-Verlag, Berlin Heidelberg doi: 10.1007/ 698_2012_151.
Salomons, W., Forstner, U., 1984. Metals in the Hydrocycle. Springer-Verlag, Berlin Heidelberg doi: 10.1007/978-3-642-69325-0.

Schenone, N.F., Avigliano, E., Goessler, W., Fernández Cirelli, A., 2014. Toxic metals, trace and major elements determined by ICPMS in tissues of Parapimelodus valenciennis and Prochilodus lineatus from Chascomus Lake, Argentina. Microchem. J. 112, 127-131. https://doi.org/10.1016/j.microc.2013.09.025.

Schenone, N.F., Volpedo, A.V., Fernández Cirelli, A., 2007. Trace metal contents in water and sediments in Samborombón Bay wetland, Argentina. Wetl. Ecol. Manag. 15, 303-310. doi: 10.1007/s11273-006-9030-6.

Schumacker, R.E., Lomax, R.G., 2004. A Beginner's Guide to Structural Equation Modeling, 2nd ed. Lawrence Erlbaum Associates Inc., Mahwah, New Jersey, pp. 07430.

Skrondal, A., Rabe-Hesketh, S., 2004. Generalized latent variable models: multilevel, longitudinal, and structural equation models, Statistical Methods in Medical Research. Chapman \& Hall/CRC, Boca Raton. doi: 10.1007/BF02295939.

Smith, B.P.G., Naden, P.S., Leeks, G.J.L., Wass, P.D., 2003. The influence of storm events on fine sediment transport, erosion and deposition within a reach of the River Swale, Yorkshire, UK. Sci. Total Environ. 314-316, 451-474. https://doi.org/10.1016/ S0048-9697(03)00068-8.

van den Berg, G.A., Gustav Loch, J.P., van der Heijdt, L.M., Zwolsman, J.J.G., 2000. Geochemical behaviour of trace metals in freshwater sediments. In: Markert, B., Friese, K. (Eds.), Trace Elements - Their Distribution and Effects in the Environment. Elsevier Science, pp. 517-533. https://doi.org/10.1016/S0927-5215(00)80024-7.

van der Perk, M., 2014. Soil and Water Contamination. CRC Press Taylor \& Francis Group, Boca Raton.

van der Weijden, C.H., Middelburg, J.J., 1989. Hydrogeochemistry of the River Rhine: long term and seasonal variability, elemental budgets, base levels and pollution. Water Res. 23, 1247-1266. https://doi.org/10.1016/0043-1354(89)90187-5.

Varol, M., 2013. Dissolved heavy metal concentrations of the Kralkizi, Dicle and Batman dam reservoirs in the tigris river basin, Turkey. Chemosphere 93, 954-962. https:// doi.org/10.1016/j.chemosphere.2013.05.061.

Vega, M., Pardo, R., Barrado, E., Debán, L., 1998. Assessment of seasonal and polluting effects on the quality of river water by exploratory data analysis. Water Res. 32, 3581-3592. https://doi.org/10.1016/S0043-1354(98)00138-9.

Villeneuve, B., Piffady, J., Valette, L., Souchon, Y., Usseglio-Polatera, P., 2018. Direct and indirect effects of multiple stressors on stream invertebrates across watershed, reach and site scales: a structural equation modelling better informing on hydromorphological impacts. Sci. Total Environ. 612, 660-671. https://doi.org/10.1016/j. scitotenv.2017.08.197.

Wang, K., Qiao, Y., Li, H., Zhang, H., Yue, S., Ji, X., Liu, L., 2018. Structural equation model of the relationship between metals in contaminated soil and in earthworm (Metaphire californica) in Hunan Province, subtropical China. Ecotoxicol. Environ. Saf. 156, 443-451. https://doi.org/10.1016/j.ecoenv.2018.03.038.

WHO, 2003. Guidelines for Safe Recreational Water Environments: Coastal and Fresh Waters. World Health Organization, Geneva, Switzerland.

Wuana, R.A., Okieimen, F.E., 2011. Heavy metals in contaminated soils: a review of sources, chemistry, risks and best available strategies for remediation. ISRN Ecol. 2011, 1-20. https://doi.org/10.5402/2011/402647.

Zou, S., Yu, Y.-S., 1993. A general equation model for river water quality data. J. Hydrol. 162, 197-209. 